\title{
Liberalism and race equality in higher education: The shift from the mandatory to the persuasive
}

\section{Pilkington, Andrew and Crofts, Melanie}

Social Sciences and Law, University of Northampton, United Kingdom

\begin{abstract}
This paper examines a twenty year period to explore the salience of race equality in higher education in the UK. While research evidence accumulates to demonstrate that staff and students from minority ethnic groups continue to experience considerable disadvantage, universities throughout the period have typically remained remarkably complacent. Such complacency partly stems from the dominance in the academy of a liberal as opposed to radical perspective on equality. Universities typically see themselves as liberal and believe existing policies ensure fairness and in the process ignore adverse outcomes and do not see combating racial inequalities as a priority. The paper distinguishes two ideal typical approaches, the 'mandatory' and the 'persuasive' to the promotion of race equality and suggests that the period has witnessed the transition along a continuum from the mandatory to the persuasive. Regardless of which approach is preferred, universities are urged to have no truck with a deficit model and to see it as their responsibility to take action to ensure more equitable outcomes.
\end{abstract}

Keywords: Equality and diversity; Race and ethnicity; Higher Education; Educational policy 


\section{Introduction}

What initially prompted us to address the issue of race and higher education was the murder of a young black man, Stephen Lawrence in 1993 because of the colour of his skin. The subsequent flawed police investigation eventually led to an official inquiry chaired by Sir William Macpherson. The report published in 1999 was extraordinarily damning: 'The [police] investigation was marred by a combination of professional incompetence, institutional racism and a failure of leadership by senior officers' (Macpherson, 1999: Para 46.1). And the political response, as exemplified by the Home Secretary's response to the report, was equally forthright: 'In my view, any long-established, white-dominated organisation is liable to have procedures, practices and a culture that tend to exclude or to disadvantage non-white people' (Straw quoted in Pilkington, 2011:3). The acceptance by a senior judge and leading Minister of the charge of institutional racism was unprecedented and inaugurated what one of us has labelled 'a radical hour' when the state seemed to be serious about promoting race equality (Pilkington, 2014). The advent of the Labour government in 1997 and the subsequent publication of the Macpherson report provided a jolt to the sector. Renewed impetus was given to equality initiatives and the limitations of equal opportunity policies in generating cultural change and combating racial disadvantage were more widely recognised.

This paper surveys the two decades since 1997 to examine how the higher education sector in general and one university in particular has addressed race and ethnicity. It will draw upon a growing research literature to evaluate the major policy initiatives. We shall argue that the salience of race equality which rose dramatically in the aftermath of the publication of the Macpherson report, and the government's response to it, has not been sustained. While new policy initiatives periodically emerge, what is remarkable in my view is the failure of the higher education sector in the last twenty years to transform the experience of Black and Minority Ethnic (BME) staff and students. Racial disadvantage remains stubbornly persistent, as we shall see.

\section{The increasing focus on race equality}

For a brief period in the first few years of the new millennium, the state exerted considerable pressure on universities to address race equality. Universities were cajoled to address race equality through two strategies for higher education, notably those concerned with widening participation and human resources. The first sought to promote equality and diversity in the student body, while the second was concerned with promoting equal opportunities in staffing. In addition to these colour blind strategies, the state also for a period required universities along with other public organisations to develop race equality policies and action plans following new race relations legislation in 2000. 
One of us has evaluated these initiatives at length elsewhere (Pilkington, 2014) and therefore we will be succinct here. Colour blind government strategies to widen participation and promote equal opportunities had minimal impact in combating racial disadvantage. By contrast, the more targeted Race Relations (Amendment) Act s had more impact, at least in the sense of generating race equality policies and plans.

We need to be circumspect, however. Even when legislation had insisted on the production of race equality policies and action plans and guidance had been provided to aid the production process, the requisite policies and action plans were often initially lacking, and significant pressure had to be exerted to ensure minimal compliance (John, 2003). The reviews that formed the basis for my evaluation perforce focused on documents, but there is a danger being too reliant on documents. This is that we confuse what is written in strategic and policy documents with what actually happens in institutions (Ahmed, 2012). Since strategic and policy documents often serve as the public face of the university, an inordinate amount of time can go into getting them just right. This can mean that writing documents and having good policies becomes a substitute for action: as an interviewee in one study puts it, "you end up doing the document rather than doing the doing"' (Ahmed, 2007).

Conscious of the dangers of reliance on official documents, one of us conducted an ethnographic investigation of one university in the decade following the publication of the Macpherson report (Pilkington, 2011). The other of us has subsequently extended the investigation to 2013 (Crofts, 2013). The university is a new university in Central England and will be identified as Midshire University.

What is immediately apparent is that at different times more or less attention has been placed on race equality. At certain points, the university made a serious effort to address the issue of race equality. At other times, the issue was not on the institution's radar. The nadir was reached in 2003 when an audit revealed that the requirement under the Race Relations (Amendment) Act to develop by May 2002 a race equality policy and action plan had not been appropriately met. The university was subsequently required to resubmit its policy and action plan to the funding council within a limited time period. This provided an opportunity for race equality champions within the university to develop a robust policy and action plan and persuade senior management to put in place appropriate resources to support the policy and plan. It is noteworthy that what prompted the recovery was not the race relations legislation per se but the independent audit which indicated the university was non-compliant.

Race equality subsequently had a higher priority within the university. New governance arrangements and the arrival of two equality and diversity officers in 2004 subsequently gave equality and diversity generally and race in particular a higher profile. And there is no doubt that for some years significant progress was made. The conditions facilitating this 
included (for a period) external pressure on the university, support from some key senior staff and the presence of highly effective equality and diversity officers.

\section{The declining focus on race equality}

The middle of the first decade of the new millennium represented the university's high point in terms of addressing race equality. Since then external pressure from the government has ineluctably declined. Although lip service continues to be paid in government pronouncements and some strategies to race equality and ethnic diversity, other government agendas prompted by concerns over increasing net migration, disorder and terrorism subsequently marginalised one concerned with race equality. This is evident in relation to the way new legislation introduced by the Labour government in 2010 has been subsequently implemented.

The Equality Act 2010 extended the general duties (now labelled the public sector equality duty), initially identified in the race relations legislation, to different strands of equality, with the Equality and Human Rights Commission (EHRC), a body that had been set up earlier to replace a series of bodies focused on distinct strands of equality, being charged with having an enforcement role. Over time, however, and especially since the Coalition government (2010) and subsequent Conservative government (2015) took power, the requirements embodied in the legislation have been eroded. Thus the specific duties, enshrined in statutory codes of practice, including the requirement to have in place an equality action plan and conduct equality impact assessments have been replaced by the need, on which there is merely guidance, to publish limited data and set one or more objectives. And at the same time, the red tape challenge and the significant cut in funding for the EHRC signal that racial equality is sliding down the government's agenda.

While it would be an exaggeration to say that equality and diversity, and concomitantly race equality and ethnic diversity, have completely disappeared as policy objectives, the contrast between the policy initiatives at the beginning of the century which demanded the production of action plans and the most recent government initiative which merely 'nudge[s] universities into making the right choices and reaching out in the right ways' (Cameron, 2016: 2-3) are palpable.

The consequence of the declining salience of race equality in government pronouncements and the decreasing pressure on universities to promote race equality has been felt graphically at Midshire University. At the university, this initially entailed increasing resistance to an equality and diversity agenda, but eventually led to the disappearance of any dedicated committees or equality and diversity officers (Crofts, 2013). This development was justified in terms of mainstreaming but has in fact entailed a reversal of the progress made in the preceding years to meet the general and specific duties of the race relations legislation. 
What is remarkable is that at the same time, evidence of racial disadvantage remains stubbornly persistent. In our studies, we found the following: persistent ethnic differentials in the student experience that adversely impact on BME students and point to possible indirect discrimination; ethnic differentials in staff recruitment that adversely impact on Black and Asian applicants and point to possible indirect discrimination;(some) minority ethnic staff subject to racism and (some) White staff cynical about political correctness; an overwhelmingly White senior staff team, with no evident efforts to transform this situation; low priority given to the implementation of a race equality action plan; few staff skilled in intercultural issues; many staff not trained in equality and diversity; and few efforts made to consult Black and Asian communities (Pilkington, 2011).

We cannot of course generalise from this case study to the sector as a whole. Nonetheless, what we have found at Midshire University resonates with findings elsewhere (Bhopal, 2015) and points to 'the sheer weight of Whiteness' (Pilkington, 2014). It is impossible to comprehend the persistence of racial disadvantage and the failure to combat this without recognising 'how deeply rooted Whiteness is throughout the ... system' (Gillborn 2008: 9. For White staff (including White researchers), however'... the Whiteness of the institution [frequently] goes unnoticed and is rationalised into a day-to-day perception of normality' (Law, Phillips, and Turney 2004, 97). It is crucial therefore that we are reflexive and do not let 'the "whiteness" of the academy ... .go unnoticed and uncommented' (Clegg, Parr, and Wan, 2003, 164; Frankenberg, 2004).

\section{Continuing racial disadvantage in the HE sector: BME staff and students}

Research continues to demonstrate that individuals from minority ethnic communities disproportionately experience adverse outcomes (Grove, 2015). While there is some variability by ethnic group since BMEs are by no means a homogeneous category, BME staff and students experience considerable disadvantage. BME academic staff are more likely to be on fixed term contracts, continue to experience significant disadvantage in career progression, especially in gaining access to the senior ranks of university management, and there remains an ethnic pay gap virtually 2 decades after the publication of the Macpherson report (Leathwood et al, 2009; ECU, 2011; Ratcliffe and Shaw, 2014)). Indeed a recent report based on interviews with BME staff is sceptical that much has changed in the last 20 years: the vast majority continue to experience subtle racism and feel outsiders in the White space of the Academy (Bhopal, 2015). Meanwhile BME students continue to be less likely to be enrolled at elite universities (UCAS, 2016) and awarded good honours degrees even when prior attainment and socio-economic status have been taken into account (Broeke \& Nicholls, 2007; HEA, 2008), and to experience lower retention rates and progression rates from undergraduate study to both employment and postgraduate study (OFFA, 2016; HEFCE, 2016). In this context it is not altogether surprising that they express significantly less satisfaction with their university experience 
(Havergal, 2016). And yet, despite this evidence of the remarkable persistence in racial disadvantage, universities are extraordinarily complacent.

\section{Legislation and equality}

This complacency partly stems from the dominance in the academy and much of society of a liberal perspective on equality. We can distinguish two broad perspectives on equality liberal and radical. The first is concerned to promote fair or like treatment and to this end seeks to devise 'fair procedures' so that everybody, regardless of race, receives the same treatment and 'justice is seen to be done' (Noon \& Blyton, 1997: 177). The emphasis in this approach is upon sanctions against any form of racially discriminatory behaviour. The second 'represents a more radical approach since it suggests that policy makers should be concerned with the outcome, rather than the process, and should therefore be seeking to ensure a fair distribution of rewards' (Noon \& Blyton, 1997: 182). To treat everybody the same is, in this view, to ignore pertinent differences between people and does little to eradicate disadvantage which stems from discrimination in the past and current institutional practices which result in indirect discrimination. To ensure fair outcomes - such as an ethnically balanced workforce - what are needed are not merely sanctions against racial discrimination but measures which entail positive discrimination i.e. preferential treatment of disadvantaged groups.

The government's major response to the Macpherson report was, as we have argued above, a legislative initiative, the Race Relations (Amendment) Act (RRAA), 2000. While this Act, like previous race relations legislation, was partly informed by the liberal perspective and thus prohibited unlawful discrimination (including positive discrimination), the Act was also informed by the radical perspective and adopted an approach that required public bodies to take the lead in eliminating racial discrimination, promoting good race relations and facilitating equal opportunities. To this end universities were required to produce race equality action plans in order to facilitate fair outcomes. Unfortunately, many of the key players in the university sector adopt a liberal perspective on equality and believe fair procedures are what is important (Deem et al, 2005; Crofts, 2013). They see themselves as liberal and believe existing policies ensure fairness and in the process ignore adverse outcomes and do not see combating racial/ethnic inequalities as a priority. This points in our view to the sheer weight of whiteness (if not institutional racism) which will remain intact unless significant pressure is placed on universities to change. 


\section{What is to be done?}

This paper is written from a particular standpoint, notably a commitment to 'building a socially justsystem of higher education' (Furlong \& Cartmel, 2009, 104)). Universities, from this perspective, will not be able to promote race equality and combat the adverse outcomes faced by BME staff and students unless they see it as their responsibility to take ameliorative action. No truck should be given to a deficit model which explains away the racial disadvantage faced by BME staff and students evidenced above. While there may be no easy answers, the key starting point is for universities to ask what they can do to ensure more equitable outcomes. Do we have forums which enable us effectively to consult with BME staff and students? What measures need to be taken to ensure diversity in leadership? Are there unconscious biases in selection and promotion boards at play which need to be dismantled? And so on.

We can distinguish two ideal typical approaches.

The first is sceptical as to whether universities will as a matter of course promote race equality and ethnic diversity. External pressure in this view is vital to facilitate change. To this end, the first approach believes that legislation and the enforcement of that legislation are crucial; sees a need for there to be a focus on race equality rather than equality in general; adopts a radical perspective on equality; identifies the need for action plans with clear targets which are regularly audited; requires publication of time series and comparative data to ensure transparency; and identifies the need for periodic inspection by an independent body.

The second approach is very different in visualising universities as having an inherent interest in promoting race equality and ethnic diversity in a highly competitive global marketplace where universities compete for students and require a diverse workforce. Legislation compelling universities to act in particular ways, according to this approach, is less effective than nudges and persuasion to remind them to utilise appropriate data to identify and dismantle barriers to equal opportunities for individuals from disadvantaged groups. Rather than imposing mandatory requirements, it is deemed preferable for universities to set their own objectives in the light of their own particular circumstances, Independent bodies ideally will identify good practice and disseminate it widely to the sector and even give awards to those universities who manifest good practice. In the process, universities will not merely comply with external demands but steadily transform themselves.

While neither of these two approaches can be found in their pure form in the real world, there is little doubt that the period we have examined has witnessed the transition from an approach close to the first ideal type to an approach close to the second. Both approaches have some merits. It is probably evident that I have greater sympathy for the first approach 
and thus welcome EHRC's recent call for a comprehensive race equality strategy (EHRC, 2016). Adoption of this approach following publication of the Macpherson report did entail some progressive change in the sector and its abandonment prevented this being sustained both at the sectoral level and at Midshire University. It would be utopian to anticipate the return of this approach in the near future. And the second approach can entail progressive change in some universities, as evidenced by those who have met the requirements for a bronze award of the race equality charter (Bhopal, 2017).

\section{References}

Ahmed, S. (2007) "You end up doing the document rather than doing the doing": Diversity, Race Equality and the Politics of Documentation' Ethnic and Racial Studies, 30 (2), 235-256.

Ahmed, S. (2012) On Being Included: Racism and Diversity in Institutional Life, London: Duke University Press.

Bhopal, K. (2015) The Experiences of Black and Minority Ethnic Academics, A Comparative Study of the Unequal Academy, London: Routledge.

Bhopal, K. (2017) Will the Race Equality Charter Make a Difference to the White Academy? http://www.birmingham.ac.uk/news/thebirminghambrief/items/2017/02/ (last accessed 11/04/17)

Broecke, S., Nicholls, T. (2007) Ethnicity and Degree Attainment, Research report RW92, London: Department for Education and Skills.

Cameron, D (2016) Watch out universities; I'm bringing the fight for equality to you, https://www.gov.uk/government/speeches/watch-out-universities-im-bringing-the-fightfor-equality-in-britain-to-you-article-by-david-cameron (last accessed 29/06/16)

Clegg, S., Parr, S. \& Wan, S. (2003) 'Racialising Discourses in Higher Education', Teaching in Higher Education, 8 (2), 155-168

Crofts, M. (2013) The Impact of the Public Sector Equality Duties on Higher Education: A Case Study, Northampton: University of Northampton.

Deem, R., Morley, L. Tlili, A. (2005) Negotiating Equity in Higher Education Institutions, www.hefce.ac.uk/pubs/redreports/2005/rd10_05/rd10_05doc (last accessed 30/05/10).

Equality Challenge Unit (ECU) (2011) Experience of Black and Minority Ethnic Staff in Higher Education in England, London: Equality Challenge Unit.

Equality and Human Rights Commission (2016) Healing a Divided Britain: The Need for a Comprehensive Race Equality Strategy, https://www.equalityhumanrights.com/en/publication-download/healing-dividedbritain-need-comprehensive-race-equality-strategy (last accessed 16/09/16).

Frankenberg, R. (2004) 'On Unsteady Ground: Crafting and Engaging in the Critical Study of Whiteness' in Bulmer, M. and Solomos, J. (eds.) Researching Race and Racism, London: Routledge: 104-118.

Furlong, A. \& Cartmel, F. (2009) Higher Education and Social Justice, Maidenhead: Open University Press.

Gillborn, D. (2008) Racism and Education, London, Routledge. 
Grove, J (2015) 'Black and Ethnic Minorities Still have Mountains to Climb in Higher Education', Times Higher Education, 5 November.

Havergal, C. (2016) 'BME Students are not Satisfied', Times Higher Education, 9 June.

Higher Education Academy (2008) Ethnicity, Gender and Degree Attainment Project: Final Report, London: Equality Challenge Unit.

HEFCE (2016) Differences in Employment Outcomes: Comparison of 2008-09 and 201011 First Degree Graduates, http://www.hefce.ac.uk/pubs/year/2016/201618 (last accessed 15/09/16).

John, G. (2003) Review of Race Equality Policies and Action Plans in HEFCE-funded Higher Education Institutions, www.hefce.ac.uk/lgm/divers/ecu (last accessed 30/10/12)

Law, I., Phillips, D. Turney, L. (2004) (eds.) Institutional Racism in Higher Education, Stoke on Trent: Trentham Books.

Leathwood, C., Maylor, U. and Moreau, M.P. (2009) The Experience of Staff Working in Higher Education, London: Equality Challenge Unit.

MacPherson, W (1999) The Stephen Lawrence Inquiry: Report of an Inquiry by Sir William Macpherson of Cluny, London: HMSO.

Noon, M. \& Blyton, P (1997) The Realities of Work, London: Macmillan.

Office for Fair Access (OFFA) (2016) Topic briefing: BME Students, https://www.offa.org.uk/universities-and-colleges/guidance-and-usefulinformation/topic-briefings/offa-topic-briefing-bme-students/ (last accessed 28/06/16)

Pilkington, A. (2011) Institutional Racism in the Academy: A UK Case Study, Stoke on Trent: Trentham Books.

Pilkington, A (2014) 'The Sheer Weight of Whiteness in The Academy: A UK Case Study' in R. Race and V. Lander (eds) Advancing Race and Ethnicity in Education, Basingstoke: Palgrave.

Ratcliffe, R and Shaw, C. (2014) White Males Monopolise Best paid Jobs in UK Universities, Report Shows, https://www.theguardian.com/higher-educationnetwork/2014/nov/18/-sp-white-males-monopolise-highest-paid-jobs-uk-universities (last accessed 27/06/16)

UCAS (2016) UCAS Publishes First Equality Reports from Individual Universities, https://www.ucas.com/corporate/news-and-key-documents/news/ucas-publishes-firstequality-reports-individual-universities (last accessed 29/06/16) 